https://nv.nltu.edu.ua

\title{
ЕФЕКТИВНІСТЬ ТЕПЛОРОЗПОДІЛЬЧИХ ПРИСТРОЇВ СИСТЕМИ ОПАЛЕННЯ САЛОНІВ АВТОБУСІВ
}

Одним із домінуючих напрямів удосконалення конструкції автобусів є роботи з підвищення ефективності функціонування їх допоміжних систем, при цьому одночасно зі зниженням ними експлуатаційних витрат енергії, тобто покращення паливної ощадливості. На паливну ощадливість автобусів істотно впливають енергетичні витрати допоміжних агрегатів $\mathrm{i}$ систем. Щодо автобусів будь-якого класу, то однією із найбільших споживачів енергії є система опалення пасажирського приміщення і робочого місця водія. Встановлено, що реалізація завдання зниження енергетичних витрат системою опалення салонів автобусів $є$ важливою проблемою під час проєктування й експлуатації автобусів. Отримано результати випробувань і здійснено їх аналіз щодо доцільності використання опалювачів салону автобусів з одним вентилятором, замість двох. Практична значущість досліджень полягає у зменшенні кількості електродвигунів з вентиляторами та зниження енергоспоживання системою опалення салону автобусів. Під час експериментальних досліджень проведено випробування аеродинамічних характеристик опалювачів 3 двома і одним осьовим вентилятором. Випробовували продуктивність за різних значень напруги на клемах електродвигунів та теплової ефективності радіатора обігрівача - температури повітря на вході і виході 3 обігрівача. За результатами експерименту встановлено, що продуктивність обігрівача із двома вентиляторами $\epsilon$ тільки на 25 \% більша, ніж 3 одним. Це явище пояснено на основі моделювання процесу з допомогою електричної аналогії. Обгрунтовано, що за одного і того самого типу теплорозсіювального радіатора, доцільно використовувати опалювачі салону пасажирських транспортних засобів із одним вентилятором замість двох. Причиною меншої ефективності опалювачів 3 двома вентиляторами $€$ насамперед те, що аеродинамічний опір на вході двох вентиляторів $є$ удвічі більшим, ніж на одному вентиляторі. Зі збільшенням продуктивності вентилятора теплотворність радіатора зменшується. Це пов'язано з тим, що зі збільшенням повітряного потоку через серцевину радіатора, зростання зняття повітрям температури з поверхні трубок радіатора перевищує інтенсивність теплообміну між нагріваючою рідиною і внутрішньою поверхнею трубок радіатора. Для збільшення аеродинамічної ефективності опалювачів салону доцільно зменшити аеродинамічний опір на вході у вентилятор, наприклад, застосуванням вентиляторів з високими аеродинамічними характеристиками.

Ключові слова: енергетичні витрати; аеродинамічні характеристики; вентилятор; продуктивність опалювача; радіатор обігрівача.

\section{Вступ}

Одним із домінуючих напрямів удосконалення автомобільних транспортних засобів є роботи з підвищення ефективності функціонування їх допоміжних систем, водночас, одночасно зі зниженням ними експлуатаційних витрат енергії, тобто покращення паливної ощадливості. Адже відомо [5], що під час експлуатації транспортних засобів, особливо автобусів, в літній період істотно погіршується рівень теплового комфорту в салоні, основним показником якого $є$ температура навколишнього повітря. Невідповідність їі рівня оптимальному не сприятливо впливає на пасажирів і призводить до швидкої їх стомлюваності, в т.ч. й водія, що негативно позначається на безпеці дорожнього руху.

Підвищення або зниження температури погіршує самопочуття водія знижує його працездатність. При високій температурі порушуються функції мислення, уваги, пам'яті, збільшується час і зменшується точність сенсо- моторних реакцій. Внаслідок цього водій несвоєчасно зауважує зміну дорожньої обстановки, запізнюється 3 виконанням необхідних управляючих впливів, припускається помилок, швидше втомлюється.

Для створення комфортних умов водієві та пасажирам і виконання вимог, представлених в Міжгалузевих правилах з охорони праці під час експлуатації промислового транспорту, стає актуальним питання про створення сприятливого мікроклімату в салоні автобуса.

Система опалення салону автобуса покликана забезпечувати мікроклімат у межах комфортності пасажирів й підтримувати ефективну експлуатацію транспортного засобу при низькій собівартості її виготовлення. В автобусах, особливо в міських, не завжди вдається досягнути компромісу між цими показниками. Тому удосконалення системи опалення салону автобуса $є$ актуальною проблемою, позаяк іï вирішення сприяє підвищенню техніко-експлуатаційних показників і конкурентоздатності транспортних перевезень.

\section{Інформація про автора:}

Нємий Степан Володимирович, канд. техн. наук, доцент, кафедра експлуатації та ремонту автомобільної техніки. Email: sniemyj@ukr.net

Цитування за ДстУ: Нємий С. В. Ефективність теплорозподільчих пристроїв системи опалення салонів автобусів. Науковий вісник НЛТУ України. 2021, т. 31, № 1. С. 80-84.

Citation APA: Niemyi, S. V. (2021). Efficiency of heat distribution devices of the heating system of bus shows. Scientific Bulletin of UNFU, 31(1), 80-84. https://doi.org/10.36930/40310113 
Відомо $[7,8]$, що на паливну ощадливість автомобілів значно впливають енергетичні витрати допоміжних агрегатів і систем. Щодо автобусів будь-якого класу, то найбільшими споживачами енергії є системи освітлення й опалення пасажирського приміщення і робочого місця водія (табл. 1). Згідно з даними цієї таблиці, енергетичні витрати для освітлення й обігріву салонів міських автобусів становлять від 47,5 до 64,5 \% струмової продуктивності генератора, для приводу якого витрачається частка потужності двигуна - понад 4 \% [7].

Табл. 1. Витрати електричної енергії в автобусах

\begin{tabular}{|l|c|c|c|}
\hline \multirow{2}{*}{ Споживач електроенергії } & \multicolumn{3}{|c|}{$\begin{array}{c}\text { Струм навантаження } \\
\text { генератора автобусів, А }\end{array}$} \\
\cline { 2 - 4 } & $\begin{array}{c}\text { серед- } \\
\text { ній } \\
\text { міський }\end{array}$ & $\begin{array}{c}\text { великий } \\
\text { міський }\end{array}$ & $\begin{array}{c}\text { шарнірно- } \\
\text { спарений } \\
\text { особливо } \\
\text { великий }\end{array}$ \\
\hline $\begin{array}{l}\text { Максимальна струмова продук- } \\
\text { тивність генератора, А }\end{array}$ & 90 & 120 & 140 \\
\hline $\begin{array}{l}\text { Постійно і періодично діючі } \\
\text { споживачі, з них: }\end{array}$ & 15,1 & 30,0 & 37,5 \\
\hline $\begin{array}{l}\text { - освітлення салону і маршрут- } \\
\text { них написів }\end{array}$ & 27,65 & 34,4 & 52,8 \\
\hline $\begin{array}{l}\text { - система обігріву салону, зок- } \\
\text { рема: }\end{array}$ & 9,25 & 11,4 & 11,4 \\
\hline - рідинний підігрівач з помпою & 18,4 & 23 & 41,4 \\
\hline - опалювачі салону & \multicolumn{3}{|c}{} \\
\hline
\end{tabular}

Отже, реалізація завдання зниження енергетичних витрат системою опалення салонів автобусів $\epsilon$ важливою проблемою під час проєктування та експлуатації автобусів.

Об'єкт дослідження - ефективність функціонування обігрівачів пасажирського приміщення автобусів.

Предмет дослідження - теплорозподільчі пристрої у салоні автобусів.

Мета роботи - визначення ефективності теплорозподільчих пристроїв у салоні автобуса залежно від їх конструктивних особливостей, що $є$ важливою проблемою під час проєктування й експлуатації автобусів.

Для досягнення зазначеної мети визначено такі основні завдання дослідження: для мінімізації енергоспоживання системою опалення необхідно виконати комплекс науково-дослідних і дослідно-конструкторських робіт, серед яких невідкладним $є$ дослідження оптимальної продуктивності теплорозподільчих пристроїв у салоні автобуса, з огляду на вимоги мінімізації енергоспоживання, рівня шумового навантаження пасажирів, конструктивної маси та вартості.

Вирішення цього завдання потребує створення відповідних математичних моделей та виконання низки експериментальних робіт для отримання потрібних статистичних даних.

Наукова новизна отриманих результатів дослідження - вперше отримано результати випробувань і проведено їх аналіз, внаслідок чого практично і теоретично обгрунтовано доцільність використання обігрівачів салону автобусів з одним вентилятором, замість двох.

Практична значущістьь результатів дослідження зменшення в конструкціях обігрівачів салону автобусів кількості електродвигунів з вентиляторами та зниження енергоспоживання системою опалення салону автобусів.

Аналіз останніх досліджень та публікацій. У публікаціях $[7,8]$ наведено результати оцінювання енергетичних витрат двигунів автобусів на живлення агрега- тів допоміжних систем, зокрема і системи опалення автобусів.

У публікаціях $[5,11]$ наведено теоретичні залежності, які відображають параметри теплових процесів у технічних системах.

У роботі [2] наведено нові наукові положення, що стосуються висвітлення режиму прогрівання салону легкового автомобіля та впливу параметрів потоку, що набігає, на режим роботи і вимоги до вентилятора при його виборі. Їх застосування на практиці дає змогу зменшити витрати на виготовлення та експлуатацію системи опалювання і вентиляції салону автомобіля та підвищити іiі функціональні можливості.

У роботі [12] висвітлено основні аспекти формування мікроклімату на робочому місці водія. Відзначено, що найважливішим параметром мікроклімату є температура повітря в салоні транспортного засобу. Температурний комфорт водія впливає також на безпеку руху через зниження професійної працездатності в разі пониження температури повітря в салоні транспортного засобу.

У публікації [4] описано системи опалення і вентиляції та їх основних систем. Викладено методи їх проєктування. Розглянуто основні методи і пристрої для проведення стендових і експлуатаційних теплових, аеродинамічних випробувань систем опалення і вентиляції кабін транспортних засобів.

У монографії [3] висвітлено техніку і методи аерофізичних експериментів, зокрема застосування електричних аналогій для моделювання аеродинамічних процесів. У публікації $[1,9]$ наведено результати досліджень умов і показників руху міських автобусів.

Публікації у зарубіжних наукових виданнях зі зазначеної проблеми, наприклад [6, 10], відображають виключно питання кондиціювання повітря в салонах автомобілів. Однак, у наведених вище та інших вітчизняних і зарубіжних наукових працях відсутній як такий аналіз функціональних властивостей обігрівачів салону автобусів для оптимізації їх робочих характеристик і мінімізації енергоспоживання системою обігріву салону транспортних засобів.

Матеріали та методи дослідження. На сьогодні для обігріву пасажирського приміщення і робочого місця водія автобусів застосовують теплорозподільчі пристрої - обігрівачі із двома (рис. 1 і 2,a) та одним вентилятором (див. рис. 2,б). На міських і приміських моделях автобусів використовують опалювачі салону з двома осьовими вентиляторами (див. рис. 2,a).

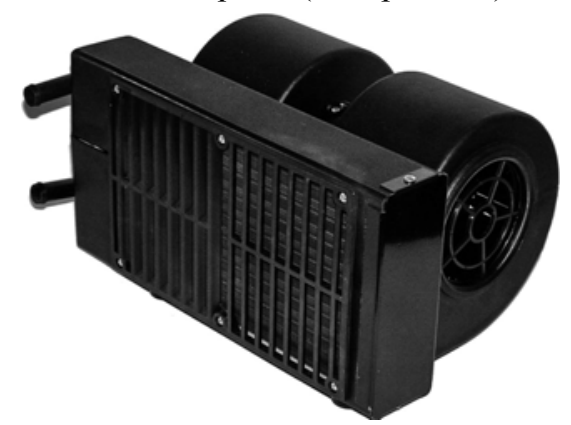

Рис. 1. Опалювач салону Термо 8000 із двома відцентровими вентиляторами (виробник Черкаський приладобудівний завод, автомобілі й автобуси ГАЗ та вітчизняні автобуси моделей РУТА, Богдан) 
Для оцінювання енергоспоживання і ефективності, 3 метою зниження витрат електроенергії було розроблено експериментальну конструкцію обігрівача салону із одним електродвигуном на тій самій корпусній базі, що i обігрівач із двома вентиляторами при теплових радіатоpax i вентиляторах однакової конструкції (див. рис. 2,б).

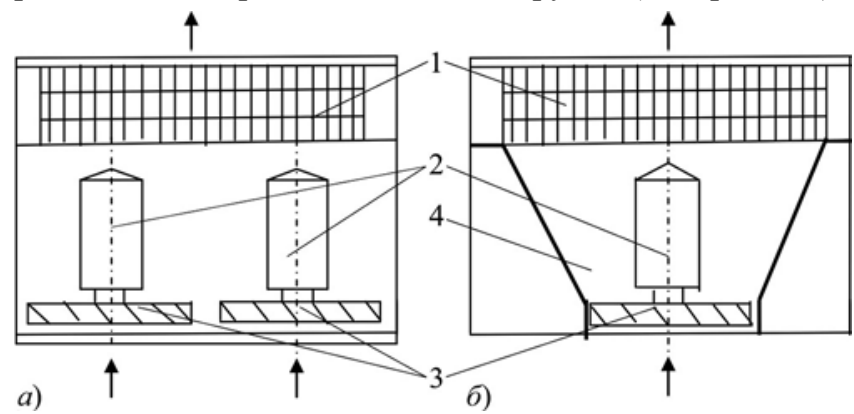

Рис. 2. Особливості конструкції досліджуваних обігрівачів салону автобусів: а) 3 двома вентиляторами; б) з одним вентилятором; 1) радіатор; 2) електродвигун; 3) вентилятор;

4) напрямний пристрій

Під час експериментальних досліджень проведено випробування аеродинамічних характеристик опалювачів 3 двома і одним осьовим вентилятором. Випробовувалася продуктивність за різних значень напруги на клемах електродвигунів та теплової ефективності радіатора обігрівача - температури повітря на вході і виході 3 обігрівача.

Значення продуктивності опалювачів, напруги на клемах електродвигунів та температури повітря на вході і виході із обігрівача визначали за загальновідомими у техніці методиками.

\section{Результати дослідження та їх обговорення}

Результати порівняльних випробувань наведено у табл. 2. На перший погляд, здавалося б, що продуктивність обігрівача 3 двома вентиляторами мала б бути удвічі більшою, порівняно із обігрівачем з одним вентилятор. Однак, як випливає із результатів експерименту (див. табл. 2), продуктивність обігрівача $W$ із двома вентиляторами тільки на 25 \% більша, ніж $з$ одним. Пояснимо це явище змоделювавши процес 3 допомогою електричної аналогії [1]. Приймаємо такі електричні аналоги аеродинамічних величин [3]: аеродинамічний напір вентилятора $H$ - електрорушійна сила $E$; продуктивність вентилятора $W$ - сила струму $I$; аеродинамічний опір на самому вентиляторі 3 двигуном $\zeta_{\text {в }}$ внутрішній опір джерела струму $r$.

Табл. 2. Результати енергетичних випробувань обігрівачів

\begin{tabular}{|c|c|c|c|c|}
\hline $\begin{array}{c}\text { Напруга } \\
\text { на клемах } \\
\text { електрод- } \\
\text { вигунів } \\
U, \mathrm{~B}\end{array}$ & $\begin{array}{c}\text { Своми вентиляторами } \\
\text { Сй струм } \\
I, \mathrm{~A}\end{array}$ & $\begin{array}{c}\text { Продуктив- } \\
\text { ність опа- } \\
\text { лювача } W, \\
\mathrm{~m}^{3} / \text { год }\end{array}$ & $\begin{array}{c}\text { Спожива- } \\
\text { ний струм } \\
I, \mathrm{~A}\end{array}$ & $\begin{array}{c}\text { Продуктив- } \\
\text { ність опалю- } \\
\text { вача } W, \\
\mathrm{~m}^{3} / \text { год }\end{array}$ \\
\hline 20 & 3,68 & 530 & 1,85 & 440 \\
\hline 24 & 4,6 & 630 & 2,3 & 525 \\
\hline 26 & 5,06 & 680 & 2,53 & 560 \\
\hline
\end{tabular}

Тоді процеси нагнітання повітря через радіатор обігрівача можна відобразити аналогом - електричними схемами, наведеними на рис. 3 .

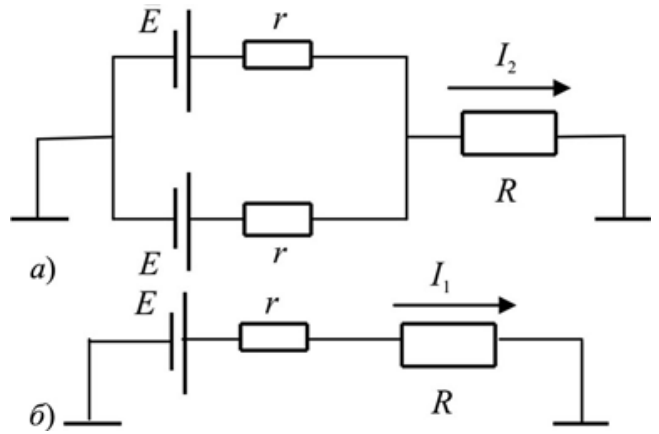

Рис. 3. Електрична аналогія процесу нагнітання повітря через радіатор обігрівача: $a$ ) із двома вентиляторами; б) з одним вентилятором

При паралельному з'єднанні $n$ однакових джерел струму електрична схема моделюється залежністю $[1,5]$

$$
E=I\left(R+\frac{r}{n}\right),
$$

де: $E$ - електрорушійна сила одного джерела; $n$ - кількість однакових джерел струму. Тоді за формулою (1) струм у колі $I_{i}$ (аналог продуктивності вентиляторів $W$ ) можна визначити за формулою

$$
I_{i}=\frac{E}{R+r / n} .
$$

Переходячи від електричних аналогів до натуральних аеродинамічних показників, згідно з формулою (2) отримаємо:

- продуктивність обігрівача з двома вентиляторами

$$
W_{2}=\frac{H}{\xi+\xi_{6} / 2}
$$

- продуктивність обігрівача з одним вентилятором

$$
W_{1}=\frac{H}{\xi+\xi_{\text {b }}} .
$$

Співвідношення продуктивностей обігрівачів обох конструкцій:

$$
\Delta W=\frac{W_{2}}{W_{1}}=\frac{\xi+\xi_{b}}{\xi+0,5 \xi_{b}} .
$$

Як випливає із результатів експериментів (див. табл. 2), $\Delta W=1,2$, а не 2,0 (через співвідношення кількості вентиляторів), як здавалося б на перший погляд.

Тоді запишемо формулу (5) так:

$$
\Delta W=\frac{\xi+\xi_{b}}{\xi+0,5 \xi_{b}}=1,2 .
$$

Виконавши відповідні математичні перетворення за формулою (6) отримаємо: $\zeta_{6}=0,5 \zeta$, тобто, у нашому випадку, аеродинамічний опір на самому вентиляторі 3 двигуном є на 50 \% менший від аеродинамічного опору радіатора обігрівача.

Як випливає із отриманих результатів, наприклад для великого міського автобуса, укомплектованого чотирма штатними обігрівачами 3 двома вентиляторами, в разі застосування обігрівачів 3 одним вентилятором i таким самим радіатором енергетичні витрати на живлення їх електродвигунів будуть на 0,22 кВт менші (за номінальної напруги на клемах електродвигунів $U=24$ В). Це дає змогу зменшити споживаний струм $I$ у балансі електроенергії майже на 9,4 А. Використання опалювачів із одним вентилятором зменшує кількість електродвигунів на автобусі, що призводить до зниження вартості виготовлення й експлуатації. 
Теплотворна здатність обігрівача безпосередньо поєднується із його продуктивністю. Однак тут основним теплоносієм є нагріте в радіаторі повітря й ефективність обігрівача абсолютно залежить від величини нагріву повітря при його проходженні через серцевину радіатора. Внутрішнім теплоносієм у радіаторах $\epsilon$ охолоджуюча двигун рідина, оскільки із нею об'єднана гідравлічна система опалення салону автобуса. Джерелом теплової енергії слугує спеціальний рідинний підігрівач.

Кількість теплоти $Q$, яка передається радіатором обігрівача, визначають із системи рівнянь [4]:

$$
\begin{gathered}
Q=c_{o p} G_{o p}\left(T_{1}-T_{2}\right) ; Q=c_{n} W\left(T_{\text {вux }}-T_{\text {вu }}\right) ; \\
Q=\frac{k_{o} S_{o}\left(T_{1}-T_{\text {вux }}\right)-\left(T_{2}-T_{\text {вx }}\right)}{\ln \left(\frac{T_{1}-T_{\text {вux }}}{T_{2}-T_{\text {gx }}}\right)},
\end{gathered}
$$

де: $c_{o p}$ - теплоємність охолоджуючої рідини (теплоносія); $G_{o p}$ - масова витрата охолоджуючої рідини через радіатор; $T_{1}$ - температура охолоджуючої рідини на вході в радіатор; $T_{2}$ - температура охолоджуючої рідини на виході із радіатора; $c_{n}$ - теплоємність повітря; $T_{\text {вux }}$ - температура повітря на виході із радіатора; $T_{b x}-$ температура повітря на вході в радіатор; $k_{o}-$ коефіцієнт теплопередачі радіатора; $S_{o}$ - площа теплопередаючої поверхні радіатора.

Аналізуючи систему рівнянь (7), бачимо, що найзручнішим для визначення кількості теплоти $Q$, яка передається радіатором обігрівача, є друге, за порядком, рівняння. Масова витрата охолоджуючої рідини через радіатор $G_{o p}$ не залежить від кількості вентиляторів і частоти їх обертання. Тоді, виходячи із другого рівняння системи (7), для оцінювання теплотворної ефективності обігрівача достатньо виміряти температури повітря на вході в радіатор $T_{6 x}$ i на виході із радіатора $T_{6 u x}$ (табл. 3).

Експеримент проводили на великому міському автобусі, оснащеному чотирма обігрівачами із одним вентилятором, на стоянці за наведеними нижче умовами:

1. Заміряно температури повітря на вході в кожний радіaтор $T_{6 x}$ i на виході із радіатора $T_{\text {виx }}$ обігрівача. Приймали середні значення.

2. Усі випробування і заміри виконували за частоти обертів вентиляторів, хв ${ }^{-1}-2210,2750$, і 3240, що відповідало напрузі живлення електродвигунів вентиляторів, B $-16,20$, i 25 .

Табл. 3. Залежність температури нагріву повітря у радіаторі обігрівачів від продуктивності їх вентиляторів

\begin{tabular}{|c|c|c|c|c|}
\hline $\begin{array}{c}\text { Частота обертів } \\
\text { вентилятора, } \mathrm{xв}^{-1}\end{array}$ & $\begin{array}{c}\text { Продуктивність вентиля- } \\
\text { тора } W, \mathrm{~m}^{3} / \text { год }\end{array}$ & $\begin{array}{c}\text { Температура повітря на } \\
\text { вході в радіатор } T_{6 x},{ }^{\circ} \mathrm{C}\end{array}$ & $\begin{array}{c}\text { Температура повітря на ви- } \\
\text { ході із радіатора } T_{\text {вих }}{ }^{\circ} \mathrm{C}\end{array}$ & $\begin{array}{c}\text { Величина нагріву } \\
\text { повітря } \Delta T,{ }^{\circ} \mathrm{C}\end{array}$ \\
\hline 2210 & 345 & 37,2 & 69,7 & 32,5 \\
\hline 2750 & 430 & 36,5 & 67,8 & 31,3 \\
\hline 3240 & 530 & 31,0 & 60,3 & 29,3 \\
\hline
\end{tabular}

Для наочності побудовано графік (рис. 4) залежності величини нагріву повітря $\left(\Delta T=T_{6 u x}-T_{6 x}\right)$, при проходженні через серцевину радіатора обігрівача, від продуктивності його вентилятора.

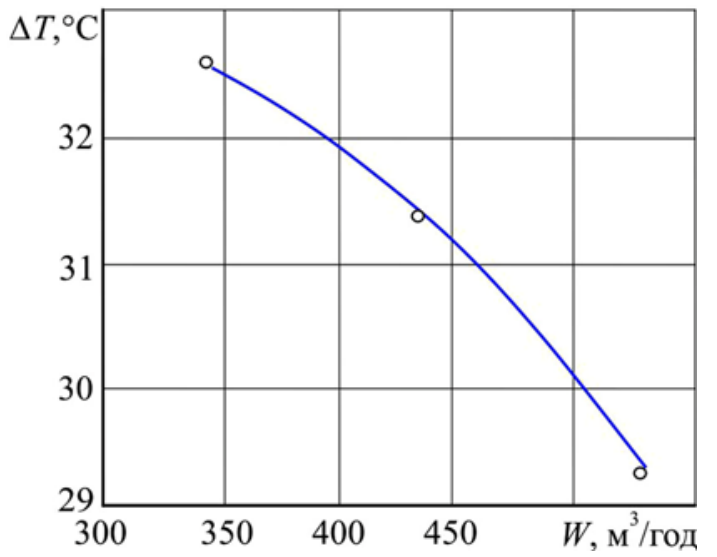

Рис. 4. Залежність величини нагріву повітря $\left(\Delta T=T_{6 u x}-T_{6 x}\right)$

від продуктивності вентилятора обігрівача

Отримано, на перший погляд, парадоксальний результат - чим більша продуктивність вентилятора, тим менший ступінь нагріву повітря при його проходженні через радіатор обігрівача. Однак такий ефект виявлено також під час досліджень, які здійснили інші автори [4] випробовуючи обігрівач кабіни водія.

У такий спосіб встановлено, що збільшення кількості повітря, що проходить через радіатор обігрівача (продуктивність вентилятора $W$ ) призводить до зменшення температури повітря на виході із радіатора обігрівача $T_{\text {виx }}$. Це пояснюють тим, що отримуваної від радіатора теплоти $Q \epsilon$ недостатньо для прогріву великої маси повітря, оскільки тепловіддача радіатора збільшується не пропорційно від кількості повітря, що проходить через нього, а по затухаючій експоненті [4].

Виходячи із отриманих результатів щодо застосування опалювачів із одним вентилятором, потрібно врахувати таке. Наприклад, для простого порівняння, у великого міського автобуса розмірністю 12 м, об'єм пасажирського приміщення $Q_{c}$ практично не перевищує $70 \mathrm{~m}^{3}$. Середня відстань між зупинками $S_{3}=350$ м, середня швидкість руху $V_{c}=5,6 \mathrm{M} / \mathrm{c}$ [9]. Тоді тривалість руху автобуса між зупинками становитиме $t_{p}=S_{3} / V_{c}=350 / 5,6=62,5 \mathrm{c}=0,017$ год.

Припускаючи, що 50 \% об'єму салону $Q_{c}$ зайнято пасажирами, об'єм повітря, яке пройшло для нагрівання через радіатори чотирьох опалювачів, становитиме $Q_{n}=4 W t_{p}=4 \cdot 530 \cdot 0,017=36 \mathrm{~m}^{3}$. Із результатів виконаних розрахунків бачимо, що впродовж часу руху між зупинками практично весь об'єм повітря салону автобуса $\left(Q_{n} \geq 0,5 Q_{c}\right)$ проходить через радіатори опалювачів і відповідно нагрівається.

Виходячи із того, що у середньому нагрів повітря опалювачами досліджуваної конструкції становить $30{ }^{\circ} \mathrm{C}$, тобто за температури зовнішнього повітря $15{ }^{\circ} \mathrm{C}$ за час руху між зупинками температура повітря, яке надійшло в салон при відкритих дверях на зупинці автобуса, нагріється до $+15^{\circ} \mathrm{C}$. Потрібно визнати, однак, що наведені твердження є орієнтовними, оскільки тут необхідно оцінити вплив наповненості салону пасажирами і тривалість зупинок на надходження холодного зовнішнього повітря в салон. Для цього доцільно провести спеціальні дослідження на міських автобусах. 


\section{Висновки}

1. Встановлено, що при одному і тому самому типі теплорозсіювального радіатора, доцільно використовувати опалювачі салону пасажирських транспортних засобів 3 одним вентилятором замість двох.

2. Причиною меншої ефективності опалювачів 3 двома вентиляторами є насамперед те, що аеродинамічний опір на вході двох вентиляторів $є$ удвічі більшим, ніж на одному вентиляторі.

3. Зі збільшенням продуктивності вентилятора теплотворність радіатора зменшується. Це пов'язано з тим, що в разі збільшення повітряного потоку через серцевину радіатора, зростання зняття повітрям температури 3 поверхні трубок радіатора перевищує інтенсивність теплообміну між нагріваючою рідиною і зовнішньою поверхнею трубок радіатора.

4. Для збільшення аеродинамічної ефективності опалювачів салону доцільно зменшити аеродинамічний опір на вході у вентилятор, наприклад, застосуванням вентиляторів 3 високими аеродинамічними характеристиками.

\section{References}

1. Gerasimov, V. G. (Ed.), Zaidel, Kh. E., Kogen-Dalin, V. V., et al. (1983). Elektrotekhnika. Moscow: Vyssh. shk., 480 p. [In Russian].

2. Hrybinichenko, M. V. (2003). Udoskonalennia systemy opaliuvannia i ventyliatsii salonu avtomobiliv ZAZ. Abstract of Candidate Dissertation. Kharkiv, 18 p. [In Ukrainian].

3. Kharitonov, A. M. (2016). Tekhnika i metody aerofizicheskogo eksperimenta. 2nd ed. Novosibirsk: Publishing NGTU, 643 p. [In Russian].
4. Khokhriakov, V. P. (1987). Ventiliatciia, otoplenie i obespylivanie vozdukha v kabinakh avtomobilei. Moscow: Mashinostroenie, 152 p. [In Russian].

5. Kukhling, Kh. (1982). Spravochnik po fizike. Trans. from Deutch. Moscow: Mir, 520 p. [In Russian].

6. Mehmet Bilgili, Ediz Cardak, \& Arif Emre Aktas. (2017). Thermodynamic Analysis of Bus Air Conditioner Working with Refrigerant R600a. European Mechanical Science, 1(2), 69-75.

7. Niemyi, S. V. (2010). Rozrakhunok enerhetychnykh vytrat dlia pryvodu avtomobilnykh heneratoriv. Bulletin of the National University "Lviv Polytechnic". Series: Dynamics, Durability and Design of Machines and Devices, 678, 83-88. [In Ukrainian].

8. Niemyi, S. V. (2015). Enerhetychna struktura avtomobilnoho transportnoho zasobu. Bulletin of the National University "Lviv Polytechnic". Series: Dynamics, Durability and Design of Machines and Devices, 820, 90-96. [In Ukrainian].

9. Niemyi, S. V. (2016). Doslidzhennia shvydkisnoho rezhymu rukhu miskykh avtobusiv. Bulletin of the National University "Lviv Polytechnic". Series: Dynamics, Durability and Design of Machines and Devices, 838, 202-211. [In Ukrainian].

10. Şaban, Ünal. (2017). An Experimental Study on a Bus Air Conditioner to Determine its Conformity to Design and Comfort Conditions. Yildiz Technical University Press, 1089-1101.

11. Uong, Kh. (1979). Osnovnye formuly $i$ dannye po teploobmenu dlia inzhenerov. Trans. from English. Spravochnik. Moscow: Atomizdat, 216 p. [In Russian].

12. Volodaretc, N. V. (2017). Kharakteristika i trebovaniia k optimalnomu obespecheniiu optimalnogo temperaturnogo sostoianiia rabochego mesta voditelia transportnogo sredstva. Avtomobilnyi transport $i$ avtomobilebuduvannia. Novitni tekhnolohii i metody pidhotovky fakhivtsiv. Naukovi pratsi Mizhnarodnoi naukovopraktychnoi konferentsii, (pp. 74-75), 19-20 zhovtnia 2017 yahr. Kharkiv. [In Ukrainian].

S. V. Niemyi

Lviv Polytechnic National University, Lviv, Ukraine

\section{EFFICIENCY OF HEAT DISTRIBUTION DEVICES OF THE HEATING SYSTEM OF BUS SHOWS}

One of the dominant areas of improving the design of buses is to improve the efficiency of their auxiliary systems, while reducing their operating energy costs, i.e. improving fuel economy. The fuel efficiency of buses is significantly affected by the energy costs of auxiliary units and systems. As for buses of any class, one of the largest consumers of energy is the heating system of the passenger compartment and the driver's workplace. It is revealed that the implementation of the task of reducing energy costs by the heating system of bus cabins is an important problem in the design and operation of buses. The test results were obtained and analyzed for the feasibility of using bus cabin heaters with one fan instead of two. The practical significance of the research is to reduce the number of electric motors with fans and reduce the energy consumption of the bus interior heating system. The test results were obtained and analyzed for the feasibility of using bus cabin heaters with one fan instead of two. The practical significance of the research is to reduce the number of electric motors with fans and reduce the energy consumption of the bus interior heating system. During experimental researches tests of aerodynamic characteristics of heaters with two and one axial fan were carried out. Performance at different values of voltage at the terminals of electric motors and thermal efficiency of the heater radiator - air temperature at the inlet and outlet of the heater were tested. As a result of the experiment, the performance of a heater with two fans was found to be only $25 \%$ higher than with one. This phenomenon is explained on the basis of process modeling using electrical analogy. It is substantiated that at the same type of the heat-dissipating radiator, it is expedient to use heaters of salon of passenger vehicles with one fan instead of two. The reason for the lower efficiency of heaters with two fans is primarily that the aerodynamic resistance at the inlet of two fans is twice as high as on one fan. With increasing fan performance, the heat capacity of the radiator decreases. This is due to the fact that as the air flow through the radiator core increases, the increase in air temperature from the surface of the radiator tubes exceeds the intensity of heat exchange between the heating fluid and the inner surface of the radiator tubes. To increase the aerodynamic efficiency of the cabin heaters, it is advisable to reduce the aerodynamic resistance at the entrance to the fan, for example, by using fans with high aerodynamic characteristics.

Keywords: energy consumption; aerodynamic characteristics; fan; heater performance; heater radiator. 